\title{
The Effect of Green Accounting on Corporate Sustainability and Financial Performance
}

\author{
I Dewa Made ENDIANA ${ }^{1}$, Ni Luh Gd Mahayu DICRIYANI², \\ Md Santana Putra ADIYADNYA ${ }^{3}$, I Putu Mega Juli Semara PUTRA ${ }^{4}$
}

Received: September 10, 2020 Revised: November 08, 2020 Accepted: November 16, 2020

\begin{abstract}
Though their activities, companies have an impact on environmental problems and nature conservation. The accounting sector can play a role in environmental conservation efforts related to environmental costs, and the implemention of the Corporate Sustainability Management System (CSMS) could be a key factor that can improve the company's financial performance. This study aims to determine how green accounting through the application of CSMS can improve the financial performance of manufacturing companies in Indonesia, a developing country. The sampling method used was purposive sampling, while the research sample consisted of 38 companies that had followed PROPER and were indexed on the IDX. Data were analyzed using the Structural Equation Modeling (SEM) method known as the Partial Least Square (PLS) method. The results of this study indicate that manufacturing companies in Indonesia are able to implement green accounting by allocating appropriate environmental costs by earmarking a portion to carry CSMS implementation so as to improve financial performance. People in Indonesia consider that manufacturing companies that have good company rankings in the evaluation program for company performance ratings in environmental management run by the Indonesian Ministry of Environment are in a position to generate customer loyalty, especially in financial performance.
\end{abstract}

Keywords: Green Accounting, Financial Performance, Corporate Sustainability Management System

JEL Classification Code: Q56, Q58, G23

\section{Introduction}

The increasingly numerous and varied human activities have an impact on the natural environment. People in meeting their daily needs can have an impact on the environment. Environmental impacts occur because humans tend to exploit natural resources from the environment in an excessive manner, not just maintaining the necessities of life. As a

${ }^{1}$ First Author and Corresponding Author. Lecturer, University of Mahasaraswati, Denpasar, Indonesia

[Postal Address: Jl Kamboja 11A, Denpasar 80236, Indonesia] Email: Made.endiana@gmail.com

${ }^{2}$ Lecturer, University of Mahasaraswati, Denpasar, Indonesia

${ }^{3}$ Lecturer, University of Mahasaraswati, Denpasar, Indonesia

${ }^{4}$ Lecturer, University of Mahasaraswati, Denpasar, Indonesia

(c) Copyright: The Author(s)

This is an Open Access article distributed under the terms of the Creative Commons Attribution Non-Commercial License (https://creativecommons.org/licenses/by-nc/4.0/) which permits unrestricted non-commercial use, distribution, and reproduction in any medium, provided the original work is properly cited. result of these human activities, the environment is damaged. Environmental damage is getting worse along with the development of industrial and technological companies. In the end, environmental damage has a negative impact on human life. On the one hand, industry has an impact on the environment, but on the other hand, the industrial world can have an impact on the economic development of a country. Companies in managing natural resources have the potential to impose negative risks on environmental aspects. For this reason, companies need to make a commitment to the environment and the social dimension as the main and inseparable part of the company's operational activities. In making it happen, the company complements its operational activities with environmental management procedures in accordance with applicable regulations, for example, the Environmental Impact Analysis Documents. Environmental management efforts aim to estimate the impact that will arise from operations, evaluate, and find appropriate solutions to overcome them.

From the increasing impact of a company's activities on environmental issues and nature conservation, the 
accounting sector can play a role in environmental conservation efforts, namely, through voluntary disclosure in its financial statements related to environmental costs. An accounting system that discloses accounts related to environmental costs is known as green accounting. Disclosure of environmental activities and environmental costs in the company's annual report will provide an overview to users of the company's financial statements, which can help users make decisions for company programs related to environmental preservation in the future. The environmental conservation program carried out by the company will be positively perceived by the community. In the end, the community will have high trust in the company. The trust that arises will encourage people to be loyal to the company. Environmental performance can have a significant effect on a company's financial position (Miroshnychenko et al., 2017). It also shows the need for adequate environmental cost information. Green accounting, in this case, is one of the sources of a company's financial performance. Besides that, corporate sustainable development also plays an equally important role.

Sustainability stands out among the most vital management paradigms that key business leaders must react to today in search of competitive success (Bansal, 2005; Fakir \& Jusoh, 2020). Bansal (2005), a leading author, argues that almost inevitably companies that do not react to sustainability will face extinction. Likewise, some say that the capability to incorporate sustainability into corporate strategy and stakeholder engagement will determine which businesses will grow in the 21 st century and which businesses will fail (Andriosopoulos, 2016; Napitupulu et al., 2020). Considering these dauntless claims, it is obviously important to know how businesses adapt to sustainability. Azapagic (2003) formulates the concept of the Corporate Sustainability Management System (CSMS) into five stages, namely, sustainable development policy, planning, implementation, communication, and review and corrective action. These five stages are conceptualized into four indicators, namely, economic, technological, social, and environmental.

Companies are currently required to improve their performance, namely by increasing their productivity. Productivity can be measured by comparing output and input during the production process. In this case, the company is required to pay attention to consumer tastes by increasing the quality and quantity of its products. In terms of increasing production, companies experience many problems that arise in relation to corporate sustainability, namely, economic, technological, social, and environmental issues, starting from the level of efficiency and effectiveness of production costs as well as the waste production process. Companies in the production process must be able to develop an integrated, comprehensive, and efficient concept of sustainable and environmentally-friendly industries. The main objective of the green manufacturing is to save the environment and to reduce the cost of the product (Paul et al., 2014). Green accounting is a concept where companies in their production process prioritize efficiency and effectiveness in using resources in a sustainable manner, so that they are able to align company development with environmental functions and can provide benefits to the community (Nga et al., 2019). The problem raised in the research is whether green accounting through the implementation of CSMS can improve financial performance. Thus, this study aims to discuss how green accounting through the implementation of CSMS can improve the financial performance of manufacturing companies in Indonesia, a developing country. Manufacturing companies generate a high level of environmental risk in Indonesia because they are directly related to the environment, where raw materials are taken directly from nature, with the impact of waste on the environment.

\section{Literature Review and Hypotheses}

\subsection{Green Accounting}

According to Cohen and Robbins (2011), green accounting is defined as: "a style of accounting that includes the indirect costs and benefits of economic activity, such as environmental effects and health consequences of business decisions and plans.”

Green accounting is a concept in which companies in their production processes prioritize efficiency and effectiveness in using resources in a sustainable manner, so that they are able to align company development with environmental functions and can provide benefits to society. In this case, the implementation of green accounting pays full attention to the concept of savings, namely, saving land, saving materials, and saving energy; it is based on the ecosystem concept. The aim of implementing green accounting is to increase the efficiency of environmental management by assessing environmental activities from the perspective of costs (environmental costs) and benefits or effects (economic benefits), as well as producing environmental protection effects. In short, the implementation of green accounting can provide information about the extent to which an organization or company makes a positive or negative contribution to the quality of human life and the environment.

Green accounting measures and recognizes environmental costs, other social costs, and presents information in the financial statements. In the last two decades, green accountants have approached one aspect of material cost accounting (Jasch, 2003; Nakajima et al., 2015). Accordingly, environmental costs include environmental protection 
costs and material flow costs (the cost of purchasing raw materials, but forming non-products). The research will focus on green accounting from an enterprise perspective. Based on the definition of green accounting above, it can be concluded that green accounting is accounting that discloses costs associated with company activities related to the environment.

\subsection{Corporate Sustainability Management System (CSMS)}

According to the US Environment Protection Agency (EPA), sustainability is based on a simple principle that can be interpreted as everything we need for the survival and well-being of life, which directly or indirectly affects the natural environment (www.epa.gov). Sustainability creates and maintains a condition in which humans and nature can live in harmony, which enables it to meet the social, economic and other needs of current and future generations. The concept of sustainability began to be introduced globally by the Brutland Commission in the Our Common Future reporting activity organized by the World Commission on Environment and Development (WCED, 1987). WCED connects sustainability with environmental and social integrity by creating a term called sustainable development which is defined as development that meets current needs without reducing the needs of future generations (WCED, 1987, p.43; (Linnenluecke \& Griffiths, 2010)

\subsection{Financial Performance}

Performance is the relative performance of the company in a similar industry, which is indicated by the company's annual return. According to Epstein et al. (2015), the company's financial performance is the result of many individual decisions made continuously by management. Therefore, to assess the financial performance of a company, it is necessary to analyze the cumulative financial and economic impacts of decisions and considering them using comparative measures. Financial performance is the determination of certain measures that can assess the success of a company in generating profits. In other words, the company's financial performance can be seen from the level of company profitability (Amacha \& Dastane, 2017; Tabash, 2019). The result shows that the majority of oil and gas companies in Malaysia had poor performance in terms of sustainability disclosure. On all three chosen profitability parameters, the companies that practiced sustainability were found to perform better than their counterparts that did not. Strong and significant relationship exists between sustainability practices and better financial performance. Financial performance is an achievement assessment of a company that can be seen from the company's ability to generate profits. Financial performance is a company work achievement that has been achieved by the company in a certain period and contained in the company's financial statements, so that one of the information that can be known by interested parties or users of financial statements to find out corporate profits (Pujiasih, 2013) Financial ratios connect various estimates contained in financial statements so that the financial condition and results of operations of a company can be interpreted (Lucyanda \& Siagian, 2012; Angelia \& Suryaningsih, 2015; Manurung \& Rachmat, 2019; Manurung et al., 2020). Financial accountability is an accurate and precise focus on reporting about the use of public funds. The main purpose is to ensure that public funds have been used for objectives that have been established efficiently and effectively (Atmadja \& Saputra, 2018).

\subsection{Green Accounting in the Corporate Sustainability Management System (CSMS)}

Accounting, especially green accounting, is expected to be able to support the sustainable development of the company. Green accounting is a part of accounting that is specifically able to manage costs related to the environment. The company's ability to apply green accounting in its business scope is expected to be able to manage costs related to the environment and, in the end, the company will be able to carry out sustainable development. Miroshnychenko et al. (2017) states that green accounting can have a significant effect on the company's financial position.

H1: Green accounting implementation is able to improve CSMS implementation.

\subsection{Green Accounting in Financial Performance}

When a company applies green accounting and is able to show a good environmental performance, the impact is on good financial performance. This has been proven in both academic and empirical research, which states that financial performance, in this case the market value of the company, is strongly influenced by environmental performance, where the effect is positive. The relationship between environmental performance and financial performance can be observed in terms of income and costs. From the income side, it can be explained that consumer preference for consumer-oriented products allows these companies to enjoy market differentiation, competitive advantages, and consumers have a tendency to be willing to pay higher prices for environmentally-oriented products (premium prices). On the cost side, there are many benefits that 
companies get as a result of increasing efficiency, avoiding potential liabilities, being better positioned to meet or exceed standards, and creating entry barriers for potential competitors. Thus, it can be explained through disclosure of environmental costs, that it will reflect the business ethics carried out by the company, as well as responsible management of resources. This will increase the social trust of stakeholders such as the public and consumers, which in turn will be able to improve financial performance, such as achieving maximum company profitability. According to Dutta et al. (2019) stated that green accounting issues relate to corporate profitability.

H2: The implementation of green accounting is able to improve the financial performance.

\subsection{Corporate Sustainability Management System (CSMS) in Financial Performance}

When integrating the concept of sustainability, the company should develop management models and strategies that will lead to the creation of social, environmental and economic values. It is necessary to set up corporate governance, which incorporate a positive response to the company's social, economic and environmental risks and opportunities that have a potential to influence performance of the organization.

\section{H3: Implementing a CMS can improve financial} performance.

\section{Research Methodology}

The population in this study was 154 companies listed on the Indonesia Stock Exchange (BEI) for the 20182019 period. This study took a sample of publicly-traded companies listed on the Indonesia Stock Exchange that participated in the Company Performance Rating Program in Environmental Management (PROPER) for 2018-2019. Purposive sampling was used, so a research sample of 38 companies was selected. The data analysis tool uses the Structural Equation Modeling (SEM) approach, known as the Partial Least Square (PLS) method. The currently drawn sample fulfills the required characteristics. In general, these characteristics are as follows:

1. The sample companies engaged in manufacturing that go public and are listed on the Indonesia Stock Exchange and publish financial reports (annual reports) in 20182019.

2. The companies selected as samples were manufacturing companies that participated in the Company Performance Rating Program in Environmental Management for 2018-2019.
Table 1: Purposive Sampling

\begin{tabular}{|l|l|c|}
\hline No & \multicolumn{1}{|c|}{ Description } & Total \\
\hline 1 & $\begin{array}{l}\text { Number of Manufacturing } \\
\text { Companies listed on the IDX for the } \\
\text { 2018-2019 Period Companies whose } \\
\text { financial statements are incompletely } \\
\text { available for the 2018-2019 period }\end{array}$ & 154 \\
\hline 2 & $\begin{array}{l}\text { Manufacturing companies that do not } \\
\text { participate in the ranking assessment } \\
\text { program in environmental } \\
\text { management successively 2018- } \\
\text { 2019 }\end{array}$ & $(116)$ \\
\hline \multicolumn{2}{|l}{ Total of sample } & 38 \\
\hline
\end{tabular}

The number of samples of PROPER companies in the period 2018 to 2019 was 38 companies, so that the number of observations was 76 , as shown in the following table.

\subsection{Green Accounting}

Green accounting is the company's performance in creating a good (green) environment. Green accounting companies are measured by the company's achievements in participating in the PROPER program, which is one of the efforts undertaken by the Ministry of Environment $(\mathrm{KLH})$ to encourage corporate governance in environmental management through information instruments. The PROPER performance rating system includes the ranking of companies in five colors, which will be scored consecutively with the highest score of 5 for gold and the lowest score of 1 for black.

\subsection{Corporate Sustainability Management System (CSMS)}

Based on Dočekalová and Kocmanová (2016), the measurement of corporate sustainability is using Complex Performance Indicator (CPI). CPI integrates the environmental, social, economic and corporate governance performance of the company. CPI contains seventeen key performance indicators, which were determined from the basic set of performance indicators using statistical methods. CPI sums up the complex corporate performance into a single value, but, at the same time, the set of aggregated sub-indicators of individual performance areas enables a detailed analysis and determination of the impact of various performance areas and factors on the complex corporate performance. Figure 1 visualizes the scheme of composite corporate performance indicator - Complex Performance Indicator. 


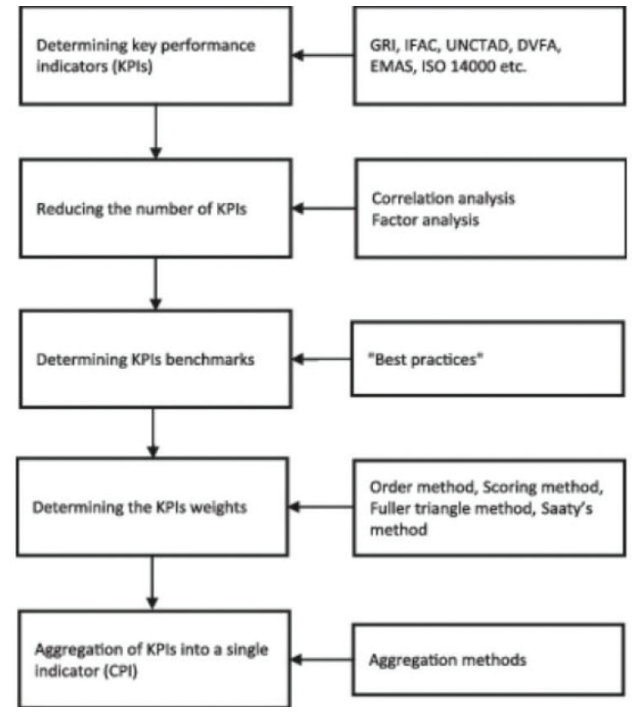

Figure 1: Complex Performance Indicator

\subsection{Financial Performance}

Performance is the relative performance of the company in a similar industry, which is indicated by the company's annual return. The company's financial performance is the result of many individual decisions made continuously by management. Therefore, to assess the financial performance of a company, it is necessary to analyze the cumulative financial and economic impacts of decisions and considering them using comparative measures. Financial performance is the determination of certain measures that can assess the success of a company in generating profits. In other words, the company's financial performance can be seen from the level of company profitability. Measurement of the profitability ratio can use ROA (Return On Asset). Return On Assets, or also known as economic profitability, is operating profit with own capital and foreign capital used to generate profits and expressed as a percentage (Platonova et al., 2018). This ratio is used to measure the rate of return on investment that the company has made using all its assets.

\subsection{Analysis}

The analysis technique used in this research is inferential statistical analysis to explain the causal relationship between variables. The inferential statistical method used in data analysis in this study is variance-based Structural Equation Modeling (SEM), which is known as the Partial Least Square (PLS) method, with the PLS warp tool. The research model is shown in Figure 2.

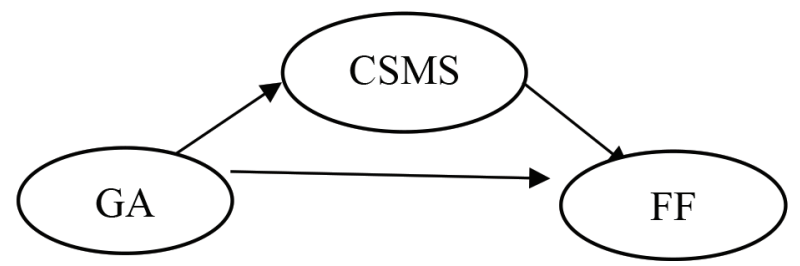

Figure 2: Research Model

GA: Green Accounting, CSMS: Corporate Sustainability Management System, FF: Financial Performance

\section{Research Results and Discussion}

\subsection{Research Results}

Based on the results of mediation analysis using PLS warp the following results are obtained:

The summary of the modeling test results is shown in Table 2.

The results of the fit model and quality indices in Table 2 indicate that the research model meets all the conditions for fit from the research model, so that it is suitable for use in explaining the population.

\subsection{Green Accounting in the Corporate Sustainability Management System (CSMS)}

The first hypothesis states that green accounting is able to improve CSMS in manufacturing companies in Indonesia. The analysis result shows that the significance is 0.01 with a coefficient of 0.15 , so that the first hypothesis can be accepted. This indicates that the increasing implementation of green accounting in manufacturing companies in Indonesia is able to increase the implementation of CSMS. Accounting in this case, especially in green accounting, proves that it is able to support the sustainable development of the company. We know that green accounting is a part of accounting that is specifically able to manage costs related to the environment. The ability of companies to apply green accounting in their business, to be able to manage costs related to the environment and to have an impact on the company will be able to carry out sustainable development. The results of this study are aligned with the research by Miroshnychenko et al. (2017) that states that green accounting can have a significant effect on the company's financial position.

\subsection{Green Accounting on Financial Performance}

The second hypothesis states that increasing green accounting can improve financial performance. The analysis results show that the significance is 0.01 with a coefficient of 0.27 . 
These results indicate that the company implementing green accounting is able to show good environmental performance, so the impact is on good financial performance. So, the second hypothesis can be accepted. The effect of green accounting with financial performance can be observed in terms of revenue and costs. Increased implementation of green accounting in manufacturing companies in Indonesia can maximize revenue potential and increase efficiency in terms of costs. On the cost side, there are many benefits that companies get as a result of increasing efficiency, avoiding potential liabilities, being better positioned to meet or exceed standards, and creating entry barriers for potential competitors. This will increase the social trust of stakeholders such as the public and consumers, which in turn will be able to improve financial performance, such as achieving maximum company profitability.

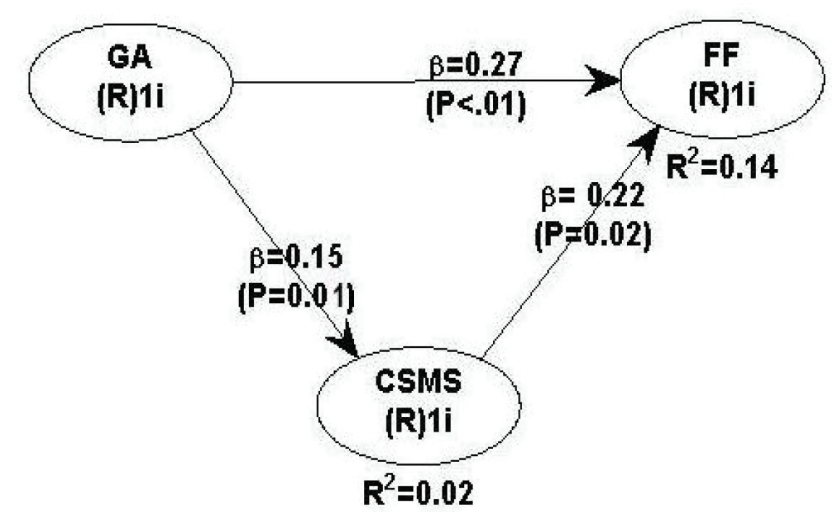

Figure 3: Research Results A

Table 2: Model fit and quality indices

\begin{tabular}{|l|}
\hline Average path coefficient $(\mathrm{APC})=0.212, \mathrm{P}=0.013$ \\
\hline Average R-squared (ARS) $=0.081, \mathrm{P}=0.118$ \\
\hline Average adjusted R-squared (AARS) $=0.063, \mathrm{P}=0.145$ \\
\hline $\begin{array}{l}\text { Average block VIF (AVIF) }=1.027, \text { acceptable if }<=5, \\
\text { ideally }<=3.3\end{array}$ \\
\hline $\begin{array}{l}\text { Average full collinearity VIF (AFVIF) }=1.103, \text { acceptable } \\
\text { if }<=5 \text {, Ideally }<=3.3\end{array}$ \\
\hline $\begin{array}{l}\text { Tenenhaus GoF }(\mathrm{GoF})=0.285, \text { small }>=0.1 \text {, medium }>= \\
0.25, \text { large }>=0.36\end{array}$ \\
\hline $\begin{array}{l}\text { Sympson's paradox ratio }(\mathrm{SPR})=1.000 \text {, acceptable if }>= \\
0.7, \text { ideally = } 1\end{array}$ \\
\hline $\begin{array}{l}\text { R-squared contribution ratio }(\mathrm{RSCR})=1.000, \text { acceptable } \\
\text { if }>=0.9, \text { ideally }=1\end{array}$ \\
\hline $\begin{array}{l}\text { Statistical suppres Zion ratio }(\mathrm{SSR})=1,000, \text { acceptable } \\
\text { if }>=0.7\end{array}$ \\
\hline $\begin{array}{l}\text { Nonlinear bivariate causality direction ratio }(\mathrm{NLBCDR})= \\
0.833, \text { acceptable if }>=0.7\end{array}$ \\
\hline
\end{tabular}

\subsection{Corporate Sustainability Management System (CSMS) in Financial Performance}

The third hypothesis states that the implementation of CSMS can improve financial performance. The results showed a significance of 0.02 with a coefficient of 0.22 , so that the hypothesis was accepted. This indicates that CSMS is able to create and maintain a condition, which can guarantee that a business can survive for a long time, so that it can lead to consumer and market loyalty so as to increase financial performance. When integrating the concept of sustainability, the company should develop management models and strategies that will lead to the creation of social, environmental and economic values.

\section{Conclusions}

Allocation of environmental costs in green accounting through the implementation of the Corporate Sustainability Management System (CSMS) is one of the strategic policies for manufacturing companies in Indonesia, so that it can improve financial performance, because it is related to company policies in allocating costs to environmental activities, investment, and funding. Therefore, the company's decision to allocate environmental costs must be in line with consumer needs and consider the company's capabilities.

The results of this study indicate that manufacturing companies in Indonesia, a developing countries, are able to implement green accounting by allocating appropriate environmental costs and in accordance with their portion so as to improve financial performance either directly or indirectly. The public assesses that companies that have a good ranking in the company performance rating program in environmental management by the Indonesian Ministry of the Environment have good prospects for financial performance.

Manufacturing companies in Indonesia, whose production process is directly related to the environment and based on the results of research that the public highly assesses companies from the perspective of their environmental responsibility, can hope to continue to maintain and improve the planning and allocation of environmental costs in the production process. The government, in this case the Indonesian Institute of Accountants (IAI), should make accounting policies and standards related to green accounting the company's legal basis for accounting. This study only examined manufacturing companies in Indonesia. Future researchers should try to use other sector companies, so they can find out whether environmental issues can occur in all types of businesses. 


\section{References}

Ali, Q., Salman, A., Yaacob, H., Zaini, Z., \& Abdullah, R. (2020). Does big data analytics enhance sustainability and financial performance? The case of ASEAN banks. Journal of Asian Finance, Economics and Business, 7(7), 1-13. https://doi. org/10.13106/jafeb.2020.vol7.no7.001

Amacha, E. B., \& Dastane, O. (2017). Sustainability Practices as Determinants of Financial Performance: A Case of Malaysian Corporations. Journal of Asian Finance, Economics and Business, 4(2), 55-68. https://doi.org/10.13106/jafeb.2017. vol4.no2.55

Andriosopoulos, K. (2016). Energy security in East Asia under climate mitigation scenarios in the 21 st century. Omega, 59, 60-71.

Angelia, D., \& Suryaningsih, R. (2015). The Effect of Environmental Performance and Corporate Social Responsibility Disclosure Towards Financial Performance (Case Study to Manufacture, Infrastructure, And Service Companies That Are Listed at Indonesia Stock Exchange). Procedia - Social and Behavioral Sciences, 211, 348-355. https://doi.org/10.1016/j. sbspro.2015.11.045

Atmadja, A. T., \& Saputra, K. A. K. (2018). Determinant factors influencing the accountability of village financial management. Academy of Strategic Management Journal, 17(1), 1-9.

Azapagic, A. (2003). Systems Approach to Corporate Sustainability A General Management Framework. Process Safety and Environmental Protection, 81(5), 303-316. https://doi. org/10.1205/095758203770224342

Bansal, P. (2005). Evolving sustainably: A longitudinal study of corporate sustainable development. Strategic Management Journal, 26(3), 197-218. https://doi.org/10.1002/smj.441

Cohen, N., and P, Robbins. (2011). Green Business: An A-to-Z Guide. Thousand Oaks, CA: Sage Publications Inc.

Clarkson, P. M., Li, Y., Richardson, G. D., \& Vasvari, F. P. (2008). Revisiting the relation between environmental performance and environmental disclosure: An empirical analysis. Accounting, Organizations and Society, 33(4-5), 303-327. https://doi. org/10.1016/j.aos.2007.05.003

Dočekalová, M. P., \& Kocmanová, A. (2016). Composite indicator for measuring corporate sustainability. Ecological Indicators, 8(945), 1-13. https://doi.org/10.1016/j.ecolind.2015.10.012

Dutta, T. K., Raju, V., \& Kassim, R. N. M. (2020). Green accounting in achieving higher corporate profitability and sustainability in ready made garment industry in Bangladesh: A conceptual analysis. International Journal of Innovation, Creativity and Change, 5(4), 181-192.

Epstein, M. J., Buhovac, A. R., \& Yuthas, K. (2015). Managing Social, Environmental and Financial Performance Simultaneously. Long Range Planning, 48(1), 35-45. https:// doi.org/10.1016/j.lrp.2012.11.001

Fakir, A. N. M. A., \& Jusoh, R. (2020). Board of gender diversity and corporate sustainability performance: Mediating role of enterprise risk management. Journal of Asian Finance, Economics and Business, 7(6), 351-363. https://doi. org/10.13106/jafeb.2020.vo17.no6.351

Hindasah, L., \& Nuryakin, N. (2020). The relationship between organizational capability, organizational learning and financial performance. Journal of Asian Finance, Economics and Business, 7(8), 625-633. https://doi.org/10.13106/jafeb.2020. vol7.no8.625

Jacobs, B. W., Singhal, V. R., \& Subramanian, R. (2010). An empirical investigation of environmental performance and the market value of the firm. Journal of Operations Management, 28, 430-441. https://doi.org/10.1016/j.jom.2010.01.001

Jasch, C. (2003). The use of Environmental Management Accounting (EMA) for identifying environmental costs. Journal of Cleaner Production, 11(6), 667-676. https://doi. org/10.1016/S0959-6526(02)00107-5

Li, Y., Gong, M., Zhang, X. Y., \& Koh, L. (2018). The impact of environmental, social, and governance disclosure on firm value: The role of CEO power. British Accounting Review, 50(1), 6075. https://doi.org/10.1016/j.bar.2017.09.007

Linnenluecke, M. K., \& Griffiths, A. (2010). Corporate sustainability and organizational learning. Journal of World Business, 45, 357-366. https://doi.org/10.1016/j.jwb.2009.08.006

Lucyanda, J., \& Siagian, L. G. (2012). The Influence of Company Characteristics Toward Corporate Social Responsibility Disclosure. The 2012 International Conference on Business and Management.

Manurung, D. T. H., Hardika, A. L., Hapsari, D. W., \& Christian, F. (2020). The affecting factors of greenhouse gases disclosure. Quality - Access to Success, 21(174), 121-127.

Manurung, D. T. H., \& Rachmat, R. A. H. (2019). Impact of ISO 14001 Implementation and Financial Performance on Corporate Social Responsibility Disclosure (Study on 2014-2016 Non Financial Companies). Journal of Management, XXIII(51), 207-222. https://doi.org/10.2991/aicar-18.2019.29

Miroshnychenko, I., Barontini, R., \& Testa, F. (2017). Green practices and financial performance: A global outlook. Journal of Cleaner Production, 147, 340-351. https://doi.org/10.1016/j. jclepro.2017.01.058

Nakajima, M., Kimura, A., \& Wagner, B. (2015). Introduction of material flow cost accounting (MFCA) to the supply chain: A questionnaire study on the challenges of constructing a lowcarbon supply chain to promote resource efficiency. Journal of Cleaner Production, 108, 1302-1309. https://doi.org/10.1016/j. jclepro.2014.10.044

Napitupulu, S., Primiana, I., Nidar, S. R., Effendy, N., \& Puspitasari, D. M. (2020). The effect of Management Capabilities in Implementing Good Corporate governance: A Study from Indonesia Banking Sector. Journal of Asian Finance, Economics and Business, 7(1), 159-165. https://doi. org/10.13106/jafeb.2020.vol7.no1.159

Nga, N. T. H., Ha, H. T. V., \& Loan, N. T. T. (2019). Green Accounting and Sustainable Development of Listed Vietnamese 
Enterprises. Journal of Asian Review of Public Affairs and Policy, 4(1), 26-42.

Paul, I. D., Bhole, G. P., \& Chaudhari, J. R. (2014). A Review on Green Manufacturing: It's Important, Methodology and its Application. Procedia Materials Science, 6, 1644-1649. https:// doi.org/10.1016/j.mspro.2014.07.149

Pujiasih (2013). The Influence of Environmental Performance on Financial Performance with Corporate Social Responsibility (CSR) as an Intervening Variable (Empirical Study of Manufacturing Companies Listed on the Indonesia Stock Exchange (BEI) 2009-2011). Semarang State University.

Platonova, E., Asutay, M., Dixon, R., \& Mohammad, S. (2018). The Impact of Corporate Social Responsibility Disclosure on Financial Performance: Evidence from the GCC Islamic Banking Sector. Journal of Business Ethics, 151, 451-471. https://doi.org/10.1007/s10551-016-3229-0

Plumlee, M., Brown, D., Hayes, R. M., \& Marshall, R. S. (2015a). Voluntary environmental disclosure quality and firm value: Further evidence. Journal of Accounting and Public Policy, 34(4), 336-361. https://doi.org/10.1016/j. jaccpubpol.2015.04.004

Tabash, M. I. (2019). An empirical investigation on the relation between disclosure and financial performance of islamic banks in the United Arab Emirates. Journal of Asian Finance, Economics and Business, 6(4), 27-35. https://doi.org/10.13106/ jafeb.2019.vol6.no4.27 